\title{
Impact of Green E-Advertisements Upon FMCG Consumers of Gujarat
}

\author{
Anjali Manglani and Tejas Dave \\ ${ }^{1}$ Department of Business Administration and Commerce, School of Liberal Studies \\ Pandit Deendayal Energy University, Raisan, Gandhinagar, Gujarat, India \\ Corresponding author email: manglanianjali133@gmail.com
}

\section{ABSTRACT}

Social media marketing is a significant tool of marketing which can influence consumers efficiently. Social media is the only platform which can reach consumers at consumer's ease. It can help society to achieve sustainability development through environment. An attempt is made by this study to help marketers to contribute in achieving this sustainable goal. The study focused on how social media marketing can help in generating awareness among consumers. The study tried to provide an insight to research objectives such as the demographic profile of consumers who are most influenced by social media marketing, the impact of promoting green FMCG products through social media marketing upon awareness among consumers of Gujarat. The sample for this study is 200 FMCG consumers selected on the basis of convenience random sampling method. For analyzing the data the techniques applied are; for efficient demographic analysis frequency distribution and percentage analysis methodology was adopted, for hypotheses analysis, One-Way ANOVA, Multiple Regression were applied. The study concluded that the target market disclosed in the study can help marketers to achieve their sustainable goal. Also, marketers need to be more conscious and need to adopt ethics in influencing the consumers through various platforms of social media.

KEY WORDS: SOCIAL MEDIA, INFLUENCE CONSUMERS, FMCG.

\section{INTRODUCTION}

Green marketing practices become well renowned since 1990. Since then it made environmental gain a challenge to society. With an expeditious gain in green marketing practices, consumers are accepting their responsibility towards environment and are adopting green products voluntarily. Green marketing is not just environment friendly practice but also helps in boosting economy by generating new job opportunities. Environment conscious consumers lead economy towards sustainability by staying loyal with green companies (Heiyantuduge Lakmal Nuwantha Perera, Ambalam Pushpanathan, 2015).

Biosc Biotech Res Comm P-ISSN: 0974-6455 E-ISSN: 2321-4007

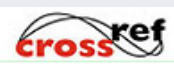

Identifiers and Pagination

Year: 2021 Vol: 14 No (5) Special Issue

Pages: 206-210

This is an open access article under Creative

Commons License Attribn 4.0 Intl (CC-BY).

DOI: http://dx.doi.org/10.21786/bbrc/14.5/38
Effective promotion is very essential for green products. Social media marketing can play a very crucial role in marketing green FMCG products. Also, FMCG is one of the largest sectors in economy. It is necessary that this sector works actively towards green (eco-friendly) practices to heal the one of the biggest section of society. The need of the hour is to bring sustainable change. For this change, every individual is required a tranquil adoption of "Green" which will lead society to sustainability. Social media can help effectively in achieving this sustainable goal. This study tried to evaluate that how social media marketing can help in generating awareness among consumers.

Literature Review: Duangruthai Voramontri, Leslie Klieb, (2018) studied consumer behavior for purchases which includes attributes like various brands, high risk, costly etc. The study implied EBM model to gather information, evaluate the same and attempt to conclude the research for making a purchase decision. The study disclosed that these all stages are included in making efficient purchase decision via social media. The conclusion added further stages such as purchase decision tends

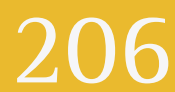


towards final purchase and after purchase feedback from consumers. Ni LuhBayuOkadiani, Ni WayanEkaMitariani, I GustiAyuImbayani, (2019) has described the marketing impact upon the products such as "Sensatia Botanical Products".

This study mainly observed the social media marketing and its impact upon green consumer behavior. All the green products marketed upon social media associated with "Sensatia Botanical" are taken as main green product for the study. The study concluded that attribute green has significant impact upon green consumers but social media was unable to influence consumers effectively. Ramesh M., Samudhra Rajakumar C. (2019) has tried to explore the impact of attributes attached with green packaging upon consumers of online market. The attributes of green product which could influence most among online consumers were "green label, green packaging, green advertisement, price, shelf life, customisation, and green awareness." The study concluded that all the green attributes has influenced consumers except price of a green product and its advertisement.

The manufacturers need to promote green products more efficiently. Shaina Arora (2019) gained an insight of ecofriendly e-commerce, its influencing ecological factors, awareness among society regarding sustainability and impact of e-commerce with its wide network and connections upon sustainable India. The study disclosed that the buzz word "green" attracts consumers more when it's been attached with online shopping. The need is to educate consumers thoroughly with both the concepts of this era i.e. "e-commerce" and "green marketing". Rebeka-AnnaPop, ZsuzsaSaplacan, Monika-Anetta Alt, (2020) has determined the factors which leads consumer's attitude towards purchase decision by the means of social media.

The theoretical implication disclosed by external factors which has great impact upon green consumer behavior and their purchase intentions towards green cosmetics. Study concluded that this source of marketing needs strong communication skills and strategy implementation to boost consumers' motivation towards green cosmetics. Abdul Bashiru Jibril, Michael Adu Kwarteng, Michal Pilik, Elsamari Botha, Christian Nedu Osakwe (2020) explored the online shopping context among consumers with demographics including educated and young population. The consumers were from Ghana, Africa. The study was explored with the "stimulus-organismresponse (SOR) framework." The study concluded that the above defined factors were the predictors which may help any marketer in exploring consumer behavior towards new technologies.

Table 1. Frequency Distribution of Aware Consumers

\begin{tabular}{|l|c|c|c|c|}
\hline Consumers & Frequency & Percent & Valid Percent & Cumulative Percent \\
\hline Aware & 94 & $47 \%$ & $47 \%$ & $47 \%$ \\
\hline Unaware & 106 & $53 \%$ & $53 \%$ & $100 \%$ \\
\hline Total & 200 & $100 \%$ & $100 \%$ & \\
\hline
\end{tabular}

Table 2. Demographic Profile of Consumers gaining Awareness through Social Media Platforms

\begin{tabular}{|l|c|c|c|}
\hline Particulars & Demographics & $\begin{array}{c}\text { Frequency } \\
\text { (Out of 94 consumers) }\end{array}$ & $\begin{array}{c}\text { (94 is considered as 100\% } \\
\text { Percentage } \\
\text { with reference } \\
\text { to aware sample) }\end{array}$ \\
\hline Age & $15-30$ & 53 & $56.4 \%$ \\
\hline Gender & Female & 56 & $59.6 \%$ \\
\hline Educational & Graduate \& & 33 & $35.1 \%$ \\
\hline \multirow{2}{*}{ Qualification } & Post-Graduate & 33 & $35.1 \%$ \\
\cline { 2 - 4 } & Professionals & 29 & $30.9 \%$ \\
\hline Monthly Income & 0-25,000 & 43 & $45.7 \%$ \\
\hline Marital Status & Unmarried & 48 & $51.1 \%$ \\
\hline
\end{tabular}

\section{Research Objectives:}

1. To review the demographic background of social media users

2. To analyze the impact of social media marketing in creating awareness among consumers of Gujarat for green marketing practices in Indian FMCG sector.

3. To generate implications to make green e-advertisements more impactful upon various social media platforms. 


\section{RESEARCH METHODOLOGY}

To accomplish the objectives of study, a quantitative survey was conducted. Under the descriptive study design, a structured questionnaire was framed for 200 consumers of Gujarat. The sample for the study was selected on the basis of convenience sampling method. Online survey was conducted via Google doc. Due to covid-19 crisis to collect the data from FMCG consumers. Factor analysis was determined to test the reliability of questionnaire. The result of Cronbach Alpha was calculated as 0.964. Also, the Kaiser-Meyer-Olkin and Bartlett's Test of adequacy displayed the result 0.956 which is much higher than its significance level i.e. 0.6. The inspection of anti-image correlation matrix reveals that all our measures of sampling adequacy are well above acceptable level of 0.5. For efficient demographic analysis frequency distribution and percentage analysis methodology was adopted. For hypotheses analysis, ANOVA, Multiple Regression were applied.

Analysis and Interpretation: Environmental awareness among consumers is a great achievement for environmental marketers who genuinely promote green products through various mediums of advertisements. In order to know the extent of awareness among consumers frequency distribution was done and the results disclosed that from sample of 200, 94 consumers were aware regarding green marketing practices viz. $47 \%$ of total sample selected. The aware consumers are further distributed as per demographic profile. The below described is the most aware group which is sorted from the group of total aware consumers i.e. $47 \%$ to specify the target market of green FMCG products in Gujarat.

Table 3. Demographic Profile of Consumers gaining Awareness through Social Media Platforms

\begin{tabular}{|l|l|c|c|}
\hline Particulars & Demographics & $\begin{array}{c}\text { Frequency } \\
\text { (Out of } 48 \\
\text { consumers) }\end{array}$ & $\begin{array}{c}\text { Percentage } \\
\text { (48 is considered as } \\
\text { 100\% with reference } \\
\text { to sample gaining } \\
\text { awareness form } \\
\text { social media) }\end{array}$ \\
\hline Age & $15-30$ & 33 & $68.8 \%$ \\
\hline Gender & Female & 28 & $58.3 \%$ \\
\hline Educational Qualification & Post-Graduate & 18 & $37.5 \%$ \\
\hline Occupation & Students & 18 & $37.5 \%$ \\
\hline Monthly Income & $0-25,000$ & 28 & $58.3 \%$ \\
\hline Marital Status & Unmarried & 28 & $58.3 \%$ \\
\hline
\end{tabular}

From above specified aware consumers, many consumers gathered information about green products from various social media platforms. Social media has ability of holding its customers for a significant period of time. It affects the choice preferences of many of its regular visitors. It has a significant impact upon its users. Especially, the youth who spend maximum of their time on such networking platforms. Such impact of social media can assist marketers to promote the contemporary ideas among its viewers and can also help in expanding the selling market. For crystalline field of vision among social media marketers, a demographic profile is constructed to give an insight for target market which can get influence effectively from social media marketing and also marketers can observe the gap which is left behind. The below described is the most aware group who gathered information from various social media platforms i.e. 48 consumers, which is sorted from the group of total aware consumers i.e. $47 \%$ to specify the target market for marketers specially focusing on social media marketing of green FMCG products in Gujarat.

\section{Hypotheses of Study:}

H1a: Consumers' age group does have significant relation with generating awareness for Green FMCG Products from social media.

H1b: Consumers' gender does have significant relation with generating awareness for Green FMCG Products from social media.

H2a: Educational Qualification of consumers does play a significant role in gaining awareness from social media.

H2b: Occupation of consumers does play a significant role in gaining awareness from social media.

H3: Monthly Income of consumers doesn't have significant impact in encouraging consumers from social media for purchasing green FMCG products.

Hypotheses Testing: The descriptive data of the study was arranged in order to analyze the data. The five independent variables are Monthly Income, Occupation, Gender, Educational Qualification and Age Group. The dependent variable of the study is social media for the hypotheses testing. All five independent variables 
together explain 98\% of the variance (R Square), which is highly significant. Only $2 \%$ of variance remains unexplained. This outcome of analysis describes the high correlation of all five independent variables among themselves. For hypotheses testing further the One-way ANOVA is applied and as the result the obtained $F$ value is 2753.3. This result of ANOVA is significant as the computed value is much higher than the table value. For a significant result and for acceptance of alternate hypothesis, computed value should be higher than the table value. Also, the below described table disclosed the value of each independent variable with relation to dependent variable.

Figure 1: Hypothetical Model

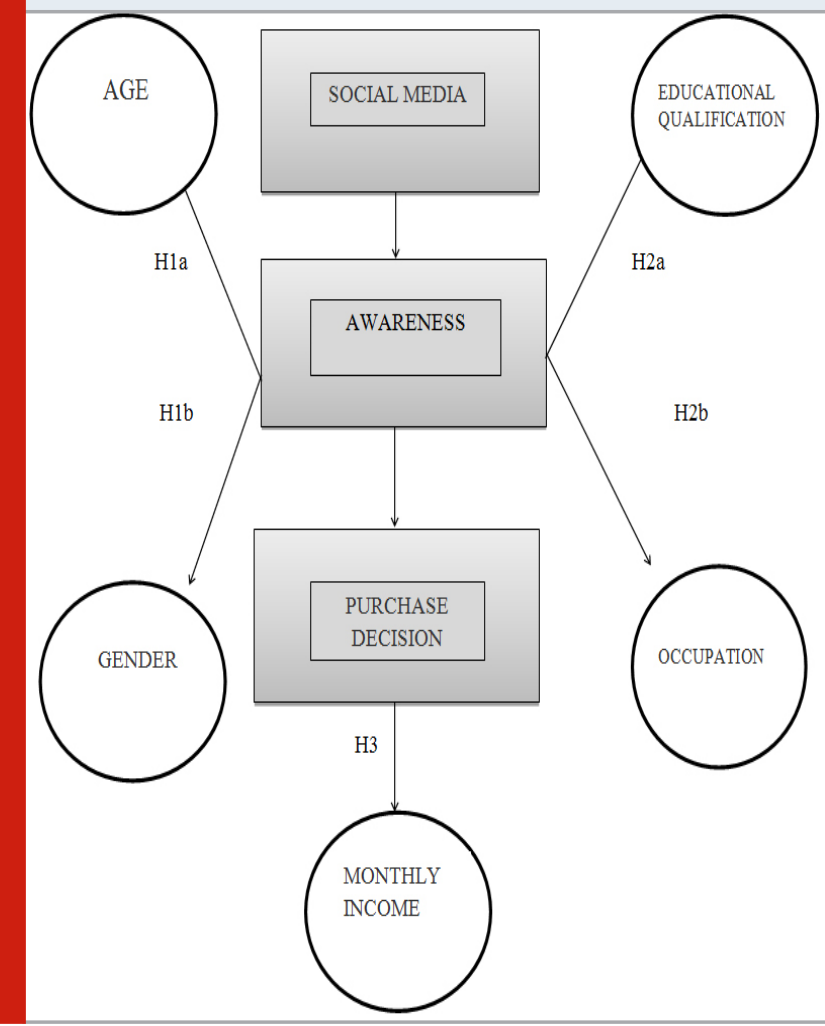

Here the table disclosed that the $\mathrm{P}$ - value is less than 0.05 for all the independent variables. As per above interpretation, a conclusion can be drawn that Social Media does play a significant role towards Green Marketing Practices in Indian FMCG Sector. The results derived that all the alternate hypotheses of the study that are accepted with significant relationship in between all independent variables and one dependent variable.

Table 4. R Square

\begin{tabular}{|l|c|c|c|}
\hline $\mathrm{R}$ & R Square & $\begin{array}{c}\text { Adjusted R } \\
\text { Square }\end{array}$ & $\begin{array}{c}\text { Std. Error } \\
\text { of the Estimate }\end{array}$ \\
\hline 0.993 & 0.986 & 0.986 & 0.055753185 \\
\hline
\end{tabular}

\section{DISCUSSIONS AND IMPLICATIONS}

The demographic interpretation and the discussion of analysis, successfully defined the demographic profile of consumers who are aware regarding green marketing practices in Indian FMCG sector. Also, the study made an attempt to comprehend the target market in front of marketers especially those demographics, who are the maximum users of social media and gets green information from social media platform, are defined specifically which can help promoters to gain the attention of consumers efficiently. Also, marketers can find the consumers who are least interested in green practices. The loophole can be diminished with effective promotional activities of attribute "Green". More specific and crystalline description of green products should be provided to motivate consumers towards the benefits of using green FMCG products.

The demographic attributes are highly correlated with each other as well as with dependent variable social media. This can help promoters to use those demographics wisely to achieve their target market. As social media is the most efficient tool for promotional activities, a sure shot can help in deriving desirable results.

\begin{tabular}{|c|c|c|c|c|c|}
\hline & Unstandardized B & $\begin{array}{l}\text { Coefficients } \\
\text { Std. Error }\end{array}$ & $\begin{array}{c}\text { Standardized } \\
\text { Coefficients Beta }\end{array}$ & $\mathrm{t}$ & Sig. \\
\hline Constant & 0.410 & 0.019 & & 21.617 & 0.001 \\
\hline Age Group & 0.133 & 0.006 & 0.257 & 23.639 & 0.001 \\
\hline Gender & 0.163 & 0.008 & 0.173 & 19.731 & 0.000 \\
\hline Educational Qualification & 0.161 & 0.005 & 0.310 & 30.759 & 0.000 \\
\hline Employment Status & 0.140 & 0.004 & 0.390 & 39.129 & 0.001 \\
\hline Monthly Income & 0.159 & 0.003 & 0.513 & 47.011 & 0.000 \\
\hline
\end{tabular}

Also, awareness regarding environmental activities can be spread using this mode properly. Youths are the most active participants on social media. The marketers should try to influence this them as they are enough capable of achieving anything towards which they are inclined firmly. So, marketers can perform well if they promote 
right information in a right way to right audience. The need of the hour is the ethical promotion of green activities and makes a sincere effort to make audience realize their responsibility towards environment and nature.

Limitation and Scope for future study: This study is limited upto the geographical boundaries of Gujarat. The sample size of study is 200. Almost all the people living in the society are FMCG consumers. FMCG market has advantage of not restricting its products with the geographical or income boundaries. Also, the promoting of Green Products and Green Practices needs to be more efficient and effective as this concept is still more or less ungrounded for maximum population. There should be efficient use of all the various sources of promotion like newspapers, television advertisements, advertisements through social media, websites of companies, etc. A wide study should be made upon this to fill up the loophole left out by promotional activities.

\section{REFERENCES}

Abdul Bashiru Jibril 1, *. ,. (2020). Towards Understanding the Initial Adoption of Online Retail Stores in a Low
Internet Penetration Context: An Exploratory Work in Ghana. Suatainability, 12(3)(854), 1-19.

Arora, S. (2019). Devising e-commerce and green e-commerce sustainability. International Journal of Engineering Development and Research, 7(2), 206210.

Duangruthai Voramontri*, L. K. (2018). Impact of Social Media on Consumer Behaviour. International Journal of Information and Decision Sciences, X(Y, xxxx), 1-25. Ni Luh Bayu Okadiani1, N. W. (2019). Green Product, Social Media Marketing and Its Influence on Purchasing Decisions. International Journal of Applied Business \& International Management, 4(3), 69-74.

Ramesh M, S. R. (2019). Determinants of Online Purchase Decision of Green Products. International Journal of Engineering and Advanced Technology (IJEAT), 9(1), 1477-1481.

Rebeka-Anna Pop *, Z. S.-A. (2020). Social Media Goes Green-The Impact of Social Media on Green Cosmetics Purchase Motivation and Intention. Information, 11(9) (447), 1-16. 